\title{
BEEKEEPING: ORGANIC AND AGROECOLOGICAL SYSTEM OF BREEDING OF BEES IN AREIAS SETTLEMENT - HIGH PANTANAL
}

Apicultura: sistema orgânico e agroecológico de criação de abelhas no Assentamento Areias - Alto

\author{
Pantanal ${ }^{1}$
}

DOI: $10.30612 /$ re-ufgd.v6i11.8443

Sandra Verza da Silva ${ }^{* 1,2,3}$

Euclides Reuter de Oliveira ${ }^{3}$

Thaís Lemos Pereira ${ }^{4}$

Vladson Carbonari ${ }^{2,3}$

Elaine Barbosa Muniz ${ }^{5}$

Alzira Salete Menegat ${ }^{3}$

Andrea Maria de Araújo Gabriel ${ }^{3}$

Jefferson Rodrigues Gandra ${ }^{3}$

Fabio Pereira Nunes ${ }^{4}$

André Luiz Montanheri da Silva ${ }^{6}$

Jessica Castilho de Lima $^{6}$

João Paulo Guimarães Soares ${ }^{6}$

Érika Rosendo de Sena Gandra7

Recebido: $14 / 07 / 2018 \quad$ Aceito: $24 / 08 / 2019$

\begin{abstract}
Honey production has achieved good results in recent years, but the country has potential to further improve this performance. Therefore, there is a need to invest more and more in research in this area. The objective of this work was to promote, monitor and evaluate the changes in the Areias settlement, located in the municipality of Nioaque, after the implementation of organic beekeeping. We seek to explore the potential of the Pantanal flora, in a sustainable way, in the creation of honeybees Apis melífera, in Legal Reserve. It was sought to develop this activity in a collective way, as an agroecological proposal of alternative income generation and food source, gathering and sharing the scientific knowledge acquired by the professors and students of the Federal University of Grande Dourados, and the accumulated experiences of the settlers with the family production system. The monitoring and achievement of the established objectives were verified every 30 days. Individual interviews and participatory meetings were held with the group of producers of the Areias, with the objective of collecting quantitative and qualitative data related

11Trabalho apoiado pela PROEX/UFGD (Pró-Reitoria de Extensão e Cultura); CNPq (Conselho Nacional de Desenvolvimento Científico e Tecnológico), Centro Vocacional Tecnológico em Agroecologia e Produção Orgânica, em Mato Grosso do Sul e ao Núcleo de Agroecologia e Produção Orgânica em Sistema Vegetal e Animal.; 2Bolsista de Extensão - CNPq (vladsoncarbonari@gmail.com); 3Docentes da UFGD, Faculdade de Ciências Agrarias, Dourados, MS (euclidesoliveira@ufgd.edu.br); 4Mestrandos do Curso de Zootecnia/UFGD (thais-lemos01@hotmail.com); 5Docente da UNIOSTE, Marechal Cândido Rondon, PR (ebmuniz@yahoo.com.br); 6Discentes do curso de Zootecnia/ UFGD; 7Bolsista de Pós-doutorado (PNPD - Capes)/UFGD (erica.sena@gmail.com); *Autor correspondente: sandraverza@yahoo.com.
\end{abstract}


to bee management and income generation. The results were satisfactory, since the organic beekeeping promoted a positive impact in the place, through the knowledge of new techniques and applicability in the creation of the bees. In this way, this study has provided support and reflections for settlement families, technicians, managers, decision makers and society to deal with the duality of the conventional productivity system and the organic and agroecological production system.

Key words: Honey production, university extension, sustainability, environment.

Resumo: A produção de mel tem alcançado bons resultados nos últimos anos, mas o país tem potencial para melhorar ainda mais esse desempenho. Portanto, há necessidade de investir cada vez mais em pesquisas nessa área. Objetivou-se com este trabalho promover, acompanhar e avaliar as transformações no Assentamento Areias, localizado no município de Nioaque, após a implantação da apicultura orgânica. Além disso, procurou-se explorar o potencial da área pantaneira, de forma sustentável, na criação de abelhas africanizadas Apis melífera, em Reserva Legal. Buscou-se desenvolver esta atividade de maneira coletiva, como uma proposta agroecológica de geração de renda alternativa e fonte alimentar, reunindo e compartilhando os saberes científicos adquiridos pelos docentes e discentes da Universidade Federal da Grande Dourados/UFGD, e as experiências acumuladas dos assentados com o sistema de produção familiar. $\mathrm{O}$ acompanhamento e o alcance dos objetivos estabelecidos foram verificados a cada 30 dias. Entrevistas individuais e reuniões participativas foram realizadas com o grupo de produtores do assentamento de Areias, com o objetivo de coletar dados quantitativos e qualitativos relacionados ao manejo das abelhas e geração de renda. Os resultados foram satisfatórios, pois a apicultura orgânica promoveu um impacto positivo no local, por meio do conhecimento de novas técnicas e aplicabilidade na criação das abelhas. Desta forma, este estudo trouxe subsídios e reflexões para as famílias do assentamento, técnicos, gestores, tomadores de decisão e a sociedade lidarem com a dualidade do sistema convencional de produtividade e o sistema de produção orgânica e agroecológico.

Palavras-chave: Produção de mel, extensão universitária, sustentabilidade, meio ambiente.

\section{Introduction}

The organic production has been taking up more and more space in the Brazilian economic scenario and is in line with the wishes of consumers, whose seem to be more concerned with the sanitary and nutritional quality of food. Thus, although the values paid for conventional foods are lower, when compared to organic products, it is possible to notice a change in the consumer's eating habit, related to the recognition of attributes that characterize a certain product (LAGO et al., 2006).

Because this system does not use pesticides or chemical fertilizers, it promotes healthier foods and does not cause harm to people during the production process. Furthermore, it brings advantages to the soil microbial balance and stability to the plants and animals biodiversity. On the other hand, the conventional production system causes environmental and food contamination, loss of soil productivity, inadequate use of water, silting of rivers, loss of 
biodiversity, social inequality, rural exodus, among other imbalances that the organic production system could avoid or reduce significantly (REIS, 2003).

Among the activities developed in an organic production system, in the state of Mato Grosso do Sul, beekeeping stands out. This activity has been gaining ground in family agriculture, being one of the practices that most promotes the social inclusion of the rural man, especially the smallholder (GONÇALVES, 2006). And it has been interesting in income generation for small producers of rural settlements (BOTH et al., 2009). It is worth mentioning here that swarms of Africanized bees captured in the environment can produce in the first year, $20 \mathrm{~kg}$ of honey, an alternative source of income, as well as a natural and high-quality food option (PEIXOTO, 2000).

Beekeeping in an organic production system is an agroecological activity that contributes to the sustainable use of natural resources (BOTH et al., 2009), especially within settlements, where three factors related to sustainability are valued: economic, social and environmental (WOLFF e MAYER, 2012). Therefore, since the process of development of beekeeping does not occur the removal of native vegetation cover (BOTH et al., 2009), there is no degradation of the environment.

Moreover, this activity avoids further wear and tear on the settlement soils, places that were previously mostly used for sugar cane production and pasture formation. These areas underwent intensive management, often without adequate soil recovery, leading to the exhaustion of areas that, with expropriation, received landless families with few conditions to invest in rural production (MUNIZ et al., 2017). Thus, understanding the mechanisms of income generation in the settlement becomes as relevant as the concern with care in soil improvement.

Bees produce excellent products that can be consumed by the settled families, and it also provides a new source of income through the sale of the surplus production of honey, royal jelly, wax, propolis, and pollen.as well as new native swarms, which can be sold in the bee products market (WOLFF e MAYER, 2012). Additionally, the bees perform agricultural pollination services (MOREIRA, 1993) and fertilize the seeds, potentializing the local biodiversity (SEVILLAGUZMÁN, 2004). However, to family agriculture members to succeed in the production, it is necessary to invest in correct mechanisms so that they can develop their activities efficiently and find appropriate ways to reach the consumer community (MUNIZ et al., 2017).

It is known that in the settlements, the bees pollinating action can increase the productivity of crops, orchards, and pastures (BRASIL, 2004). Bees can contribute even to the production of vegetable seeds, promoting the quality and quantity of seeds, and ensuring the cross- 
fertilization among the flowers of the same crop depending on the intensity and efficiency of their visits to the flowers to collect the nectar of the plants (WOLFF and MAYER, 2012). They are also able to extract nectar and pollen from the rainforest, native forests of the Cerrado, Eucalyptus reforestation, pastures and medicinal herbs, common vegetation in most agrarian reform settlements in Mato Grosso do Sul, which qualifies them as potential areas for beekeeping.

In this context, the objective of this work was to include beekeeping in the settlers' production system and to explore the local potential, in a sustainable manner, for the creation of honey bee Apis melifera, in Legal Reserve areas, located in the Areias settlement, in the municipality of Nioaque. It was sought to develop this activity in a collective way. As an agroecological proposal, gathering and sharing the scientific knowledge related to the organic production by the teachers and students of the Federal University of Grande Dourados - UFGD, and the accumulated experiences of the settlers with the family farming system.

\section{Materials and Methods}

The apiary was installed inside of a collective use reserve with approximately 400 ha of secondary forest and is located at the Areias settlement, municipality of Nioaque, in the gateway of the Pantanal of Mato Grosso do Sul state. On the edge of the reserve, there is a stream with a riparian forest, which is covered by forest greenery or cerrado restoration. This chosen site presents a high potential for beekeeping activity due to its flora with favorable diversity for the work of the bees, in the production of honey.

The implementation of beekeeping in the Areias settlement is an initiative from the university extension projects maintained by the Federal University of Grande Dourados. Currently, this activity has the financial support of CNPq (National Council for Scientific and Technological Development): Technological Vocational Center Project in Agroecology and Organic Production, in Mato Grosso do Sul and PROEX / UFGD.

The work started in 2014, through the capture of swarms with bee lure boxes, Langstroth model (15 boxes with standardized frames), prepared and installed in a strategic location, to attract and capture native colonies in the swarming phase. Each bait box was prepared in such a way that the swarms of honey bees, in the initial phase, could choose voluntarily to occupy and settle therein. To increase the attractiveness, interest, and enthusiasm of scout bees for the new location, plant substances or aromatic plants such as lemongrass (Cymbopogon citratus) were rubbed on the inner walls of the bait hives (EMBRAPA, 2009). In addition to capturing in bait 
boxes, the beekeepers from the settlements also collected beehives in the natural environment (hollow tree trunks, abandoned mounds, etc.).

For the initial work of the group, which was composed of 10 people, the projects originated by institutions provided ten swarms of bees containing selected queens. In addition, he also provided bricks for the construction of a beekeeper's warehouse for the preparation and storage of the work materials and a complete carpentry toolkit, with recyclable wood. In this way, the settlers themselves can prepare and produce the boxes, honey super and other basic equipment necessary for beekeeping, thus eliminating the costs involved in acquiring them on the market.

During the development of this work, from the implementation to the present moment, courses were held, participative meetings and theoretical discussions with the group for planning and development of activities. The settlers were accompanied and guided by the coordinator of the extension activity and advised by several professionals of the area at each stage of the beekeeping activity. To this end, visits were made every 30 days, with theoretical and practical explanations lasting eight hours daily. At each meeting, information and technical guidance about material fabrication, swarm capture, bee management, and honey production were provided. A beekeeping calendar was also set up regarding the climatic and environmental characteristics of the region.

In addition, experiences, activity planning notes, accounting, changes and doubts of the settlers were collected, and practical tasks were set up in joint discussions that were discussed during subsequent visits. Individual interviews and participatory meetings were held with the group of producers of the Areias settlement, aiming to collect quantitative and qualitative data. The main points evaluated were bee management, local income generation and the transformations that occurred in the properties after the implementation of the organic beekeeping system.

The data were analyzed based on the spreadsheet sets of the environmental impact assessment system of agricultural technological innovations, Software Ambitec-Agro - 1.3 (RODRIGUES et al., 2005).

\section{Results and Discussion}

The organic and agroecological system of breeding of bees in the Areias settlement showed satisfactory results, but there are many adverse situations. Among them are the lack of success in capture, the loss of swarms, because today the apiary has only seven hives, six with queens selected and one made through the division of another colony (Table 1). Another factor that 
makes beekeepers often apprehensive is the long periods in which bees do not produce honey.

The success of beekeeping is related to the knowledge and improvement of the techniques used. Thus, although beekeepers in the Areias settlement are still having difficulties to capture bees, they are learning how to make bait boxes and honey super, and how to handle swarms and proper removal of honey with equipment provided by the projects. For collection of swarms, according to Soares et al. (1998), there are two time in the wild in which bees move, one of which is the swarming occurring in August, September and October, and the other in autumn when abandonment occurs, and the bees leave in search for another place to settle.

On the other hand, the technological knowledge of the queen selection technique promoted a positive effect (Table 1). The queen is the most important individual of the beehive, she is responsible for the social balance of the colony, and for the reproduction and perpetuation of the species. Thus, queens of good origin have a higher posture capacity, presenting more balanced and productive hives (WIESE, 1995). This technique seeks to reduce the loss of beehives by the abandonment of colonies and the instinct of swarming these bees, phenomena that may be occurring in the apiary of Areias.

Table 1. Amount of honeys super and identification of hives available in the apiary of the Areias settlement.

$\begin{array}{cccc}\text { Beehives } & \begin{array}{c}\text { Amount of } \\ \text { honey super }\end{array} & \begin{array}{c}\text { Beehives with } \\ \text { captured native } \\ \text { swarms }\end{array} & \begin{array}{c}\text { Beehives with selected } \\ \text { queens }\end{array} \\ 1 & 2 & - & \mathrm{X} \\ 3 & 2 & - & \mathrm{X} \\ 4 & 1 & - & \mathrm{X} \\ 6 & 2 & - & \mathrm{X} \\ 11 & 3 & - & \mathrm{X} \\ 12 & 4 & - & \mathrm{X} \\ \mathrm{A} 4 & 2 & \mathrm{X} & -\end{array}$

It is believed that the lack of initial experience of the group of beekeepers, currently composed of 6 individuals, made some of them doubt the potential of the site. However, the positive results achieved in the production of honey motivated them to return with more security, having in this activity a new source of food and income generation (by selling the surplus), improving the structure of their properties and quality of life. This practice brought together in a single working group the different experiences of each member, which associated with the 
techniques taught by UFGD teachers and experts in the field, contributed to increase the knowledge of the group regarding bee rearing and honey production.

According to the majority of beekeepers, after four years of apiary installation, this activity, in addition to increasing income diversity in the settlement has significantly increased security (guarantee of income) and financial stability (Figure 1). Worth highlighting here that beekeeping is a profitable activity that can interconnect social, economic and environmental aspects (BOTH, 2008; AMARAL, 2010), and is a practice especially indicated for the development of less favored communities (ROVIRA, 2010 ), as is the case of the settlement in question.

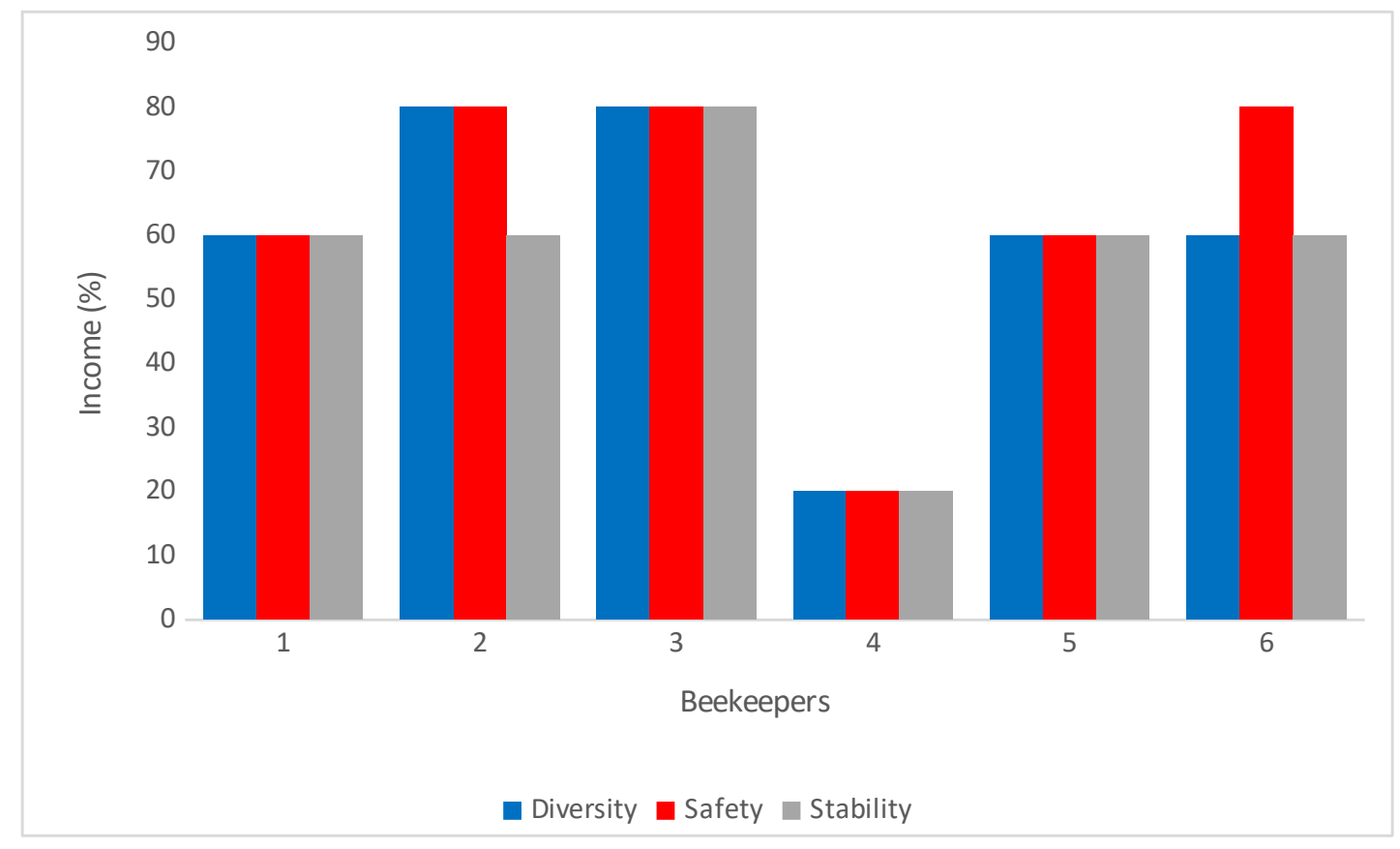

Figure 1. Generation and income diversity after the implementation of beekeeping in the Areias settlement.

In addition, it has been an activity that has brought the people closer to the settlement, with a cultural integration between the contributors and their families, who who collectively get together and plan production. In order to create means to improve living conditions, there was also greater engagement of people in social movements and capitation of demands in the community (Figure 2). Thus, as commented by Grassieli et al. (2017) in relation to collective activities in communities, one of the beneficial results, and perhaps the group is not measuring, is the sociability they are building, even in the face of conflicts, is approaching neighbors and motivating them to find alternative ways for some immediate problems.

Research with the beekeeping group in the Areias led us to understand other 
variables besides beekeeping, such as the goals and changes that the people of settlements want and after all how they live. These factors allowed them to plan possible goals to be fulfilled with the support of UFGD and CNPq.

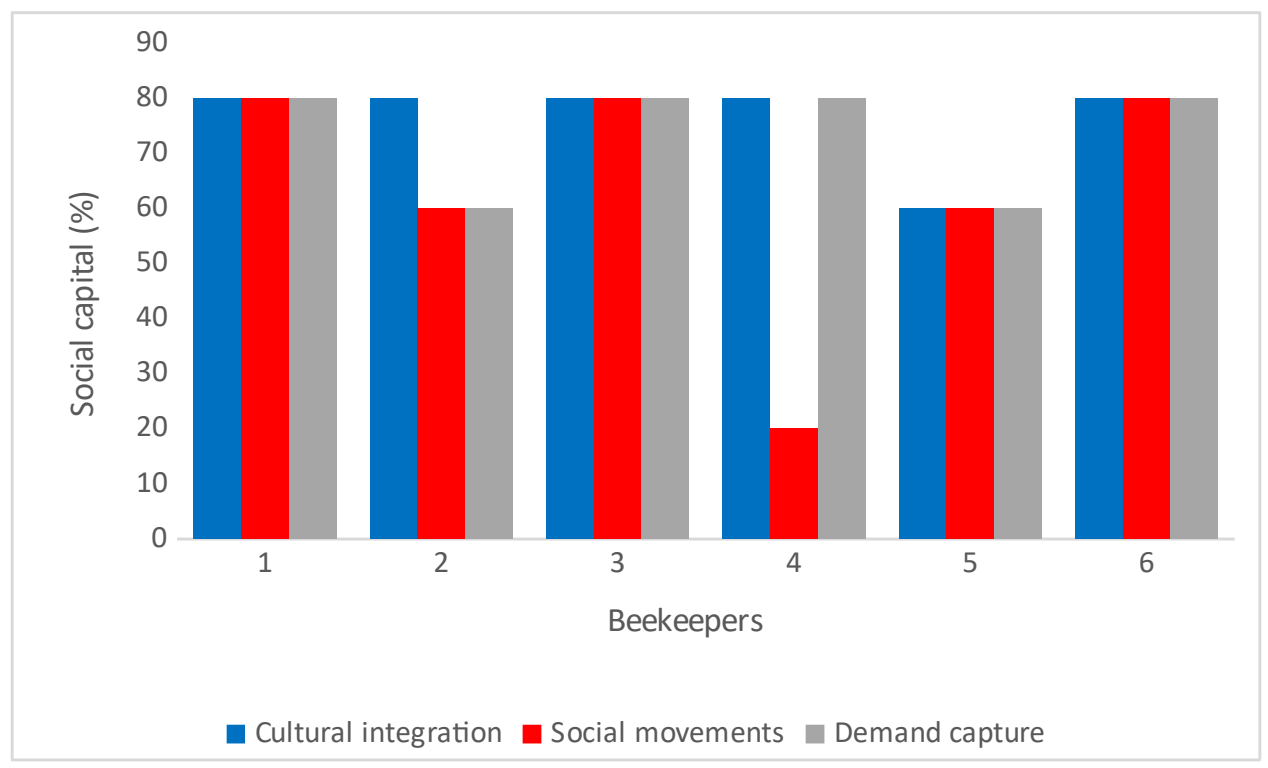

Figure 2. Social capital after the introduction of beekeeping in the Areias settlement.

The reserve area where the apiary is located in the Areias settlement is a region composed of secondary forest, where the vegetation had been totally lost by the cutting and burning method, and after 20 years it was naturally reconstituted. It is a region that is at the entrance of the Pantanal, and is a place with a large amount of forest, with rich and abundant flowering of many species of plants typical of the savannah and the wetlands, such as the Ipê-rosa (Handroanthus heptaphyllus), being characterized in an excellent place for honey production (Figure 3).

With the help of technical advice, an apicultural calendar was developed in the region around the Areias settlement, which provided a planning of activities. It is known that it is important to identify the flora around the apiary, to analyze the habit of the plants, and to verify if there is a relation between the climatic factors and the flowering season, since the knowledge of the bee flora of a region is fundamental to the rational creation of bees (LOPES et al., 2016). 

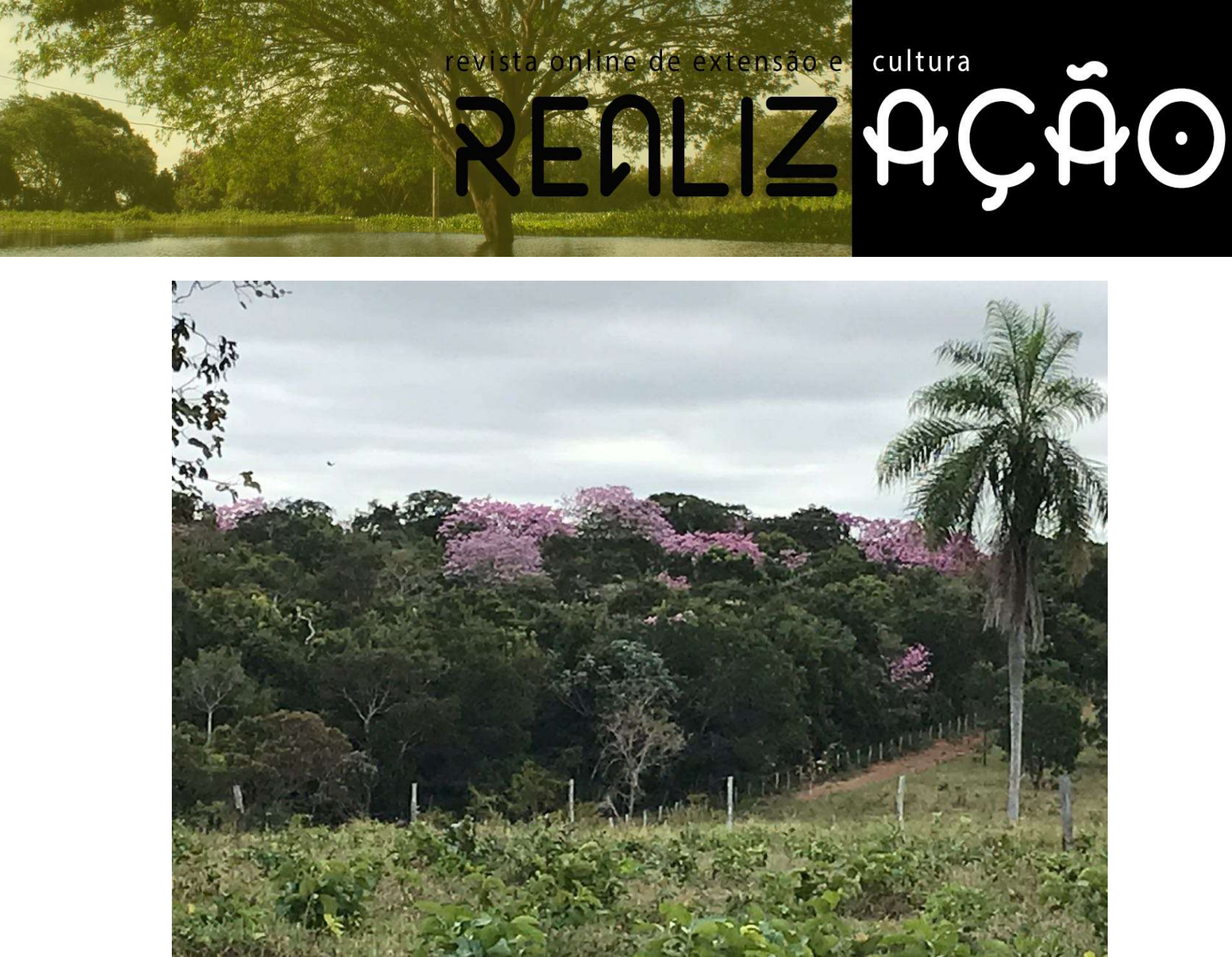

Figure 3. Partial view of the reserve area, location of the apiary facility in the Areias settlement.

It was observed that there was an awareness of the group regarding the importance of bees in the pollination process. For small farmers realized that honeybees, in addition to producing honey, enable the production of viable fruits and seeds of higher quality, thus promoting the improvement of other products grown in the settlement. They also promote a quantitative increase in grain and seed production (SOUZA et al., 2003), and assist in environmental restoration and restoration programs of the original flora (MUNIZ et al., 2017).

In order to ensure the welfare of bees in the Areias settlement, all the essential premises in the efficiency and quality of the organic system of beekeeping and animal health were followed. In this way several aspects were considered by the UFGD and settled, from the preparation and settlement of the swarms, the proper location of the apiary, the local apicultural flora, to the advanced management that guarantee the honey production, the health and productivity of the beehives.

With the objective of analyzing the results regarding the correct way of organic creation of bees, beekeepers were invited to evaluate some essential factors in the management of these social insects. The majority of the settlers classified that after some courses and orientations of the university professors and technicians in the area of beekeeping, the handling with the bees improved $60 \%$ or more in relation to the well-being and animal health. The items evaluated were: access to water and food, animal comfort, adequate stocking, safety and sanitary management, 
conditions to express natural behaviors of the species, actions that help to minimize stress and ethical management behavior, as can be seen in Figure 4.

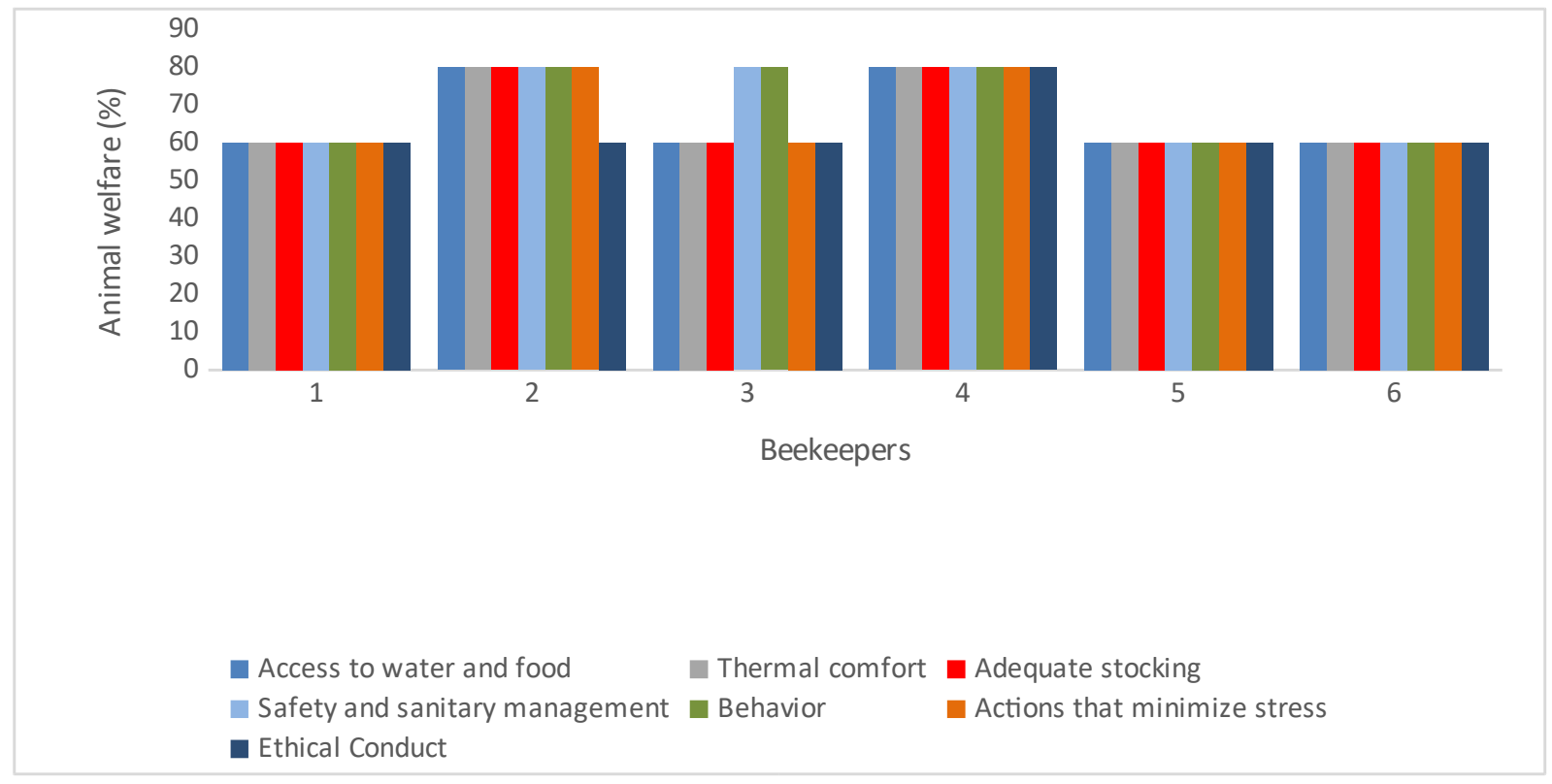

Figure 4. Evaluation of beekeepers: welfare of the bees created in the Areias settlement.

Organic beekeeping follows some principles, in which the management of hives and the cleaning of apiaries should respect the nature of the bees, their biological cycles, their behaviors and their ability to produce healthy and natural foods. Thus, animal welfare standards must be observed in all stages of the production process, favoring bee health without using external inputs that endanger the quality of bee products (WOLFF, 2010).

It is known that the success of the group can be achieved, after years of experience and collective dedication. However, the particularities of the activity will always bring challenges to the group, as they move the bees that are susceptible to environmental intemperies, and the influence of flowering bee depends on the beekeeper's experience to make medium and long term decisions (GRASSIELI et al., 2017). Therefore, working in tune and respect the nature of the animal and its environment, will be the most viable alternative for the success of the beekeeping group of the settlement Areias.

\section{Conclusion}

It is considered that this work gave beekeepers a high learning for the development of their activities involving theory and practice. Therefore, there was a positive impact through the knowledge of new techniques and applicability in bee rearing. In addition, the results of this study 


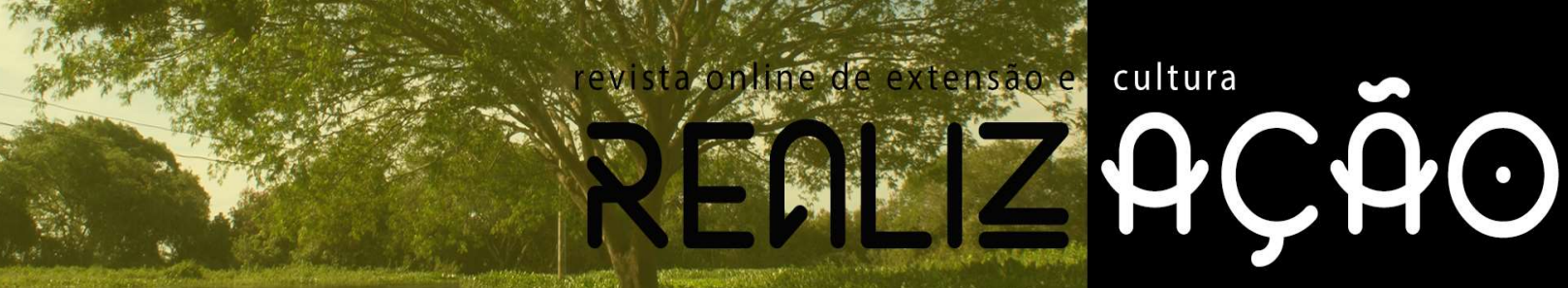

and the reflections with the community seem to contribute in a favorable way in the exploitation of sustainable resources of productive systems in the settlement, reaching the established objectives.

\section{Bibliographic References}

AMARAL, A.M. Arranjo produtivo local e apicultura como estratégias para o desenvolvimento do sudoeste de Mato Grosso. Tese (Doutorado em Ecologia e recursos naturais). Universidade Federal de São Carlos, São Carlos. 2010. 147 p.

BOTH, J.P.C.L. Mel na composição da renda em unidades de produção familiar no município de Capitão Poço, Pará, Brasil. Dissertação (Mestrado em Agriculturas familiares e desenvolvimento sustentável). Universidade Federal do Pará, Belém. 2008. 105 p.

BOTH, J.P.C.L.; BOTH, A.L.C.M.; KATO, O.R.; OLIVEIRA, T.F. Mel na Composição da Renda em Unidades de Produção Familiar no Município de Capitão Poço, Pará, Brasil. In: CONGRESSO LATINO AMERICANO DE AGROECOLOGIA E CONGRESSO BRASILEIRO DE AGROECOLOGIA, 2 e 6, 2009, Curitiba. Anais...Curitiba: Congresso Latino Americano de Agroecologia e Congresso Brasileiro de Agroecologia, 2009.

BRASIL. MINISTÉRIO DO MEIO AMBIENTE. Iniciativa brasileira de polinizadores no âmbito da iniciativa internacional para conservação e uso sustentável dos polinizadores na convenção sobre diversidade biológica. Brasília, DF, 2004. 1 CD-ROM.

EMPRESA BRASILEIRA DE PESQUISA AGROPECUÁRIA - EMBRAPA. ABC da Agricultura Familiar - como capturar enxames com caixas iscas. Embrapa Informação Tecnológica Brasília, DF. 2009.

GONÇALVES, L.S. Desenvolvimento e expansão da apicultura no Brasil com abelhas africanizadas. Revista Sebrae, v. 3, p. 14-16, 2006.

GRASSIELI, A.A.; NUNES, F.P.; MENEGAT, A.S.; OLIVEIRA, E.R.; GEISENHOFF, L.O. Organização do trabalho na produção de mel: um estudo de caso no assentamento Areias. In: MENEGAT, A.S.; FAISTING, A.L.; OLIVEIRA, E.R.; PEREIRA, Z.V. (Orgs.). Extensão rural, agroecologia e produção animal e vegetal em lotes de assentamentos rurais e sítios de colonização em Mato Grosso do Sul. Dourados-MS: Seriema, 2017. p. 17-43.

LAGO, A.; LENGLER, L.; CORONEL, D.A.; SILVA, T.N. Agricultura familiar de produtos orgânicos: Um olhar sob a ótica do marketing. Revista Extensão Rural, Santa Maria, n.13, p. 93$116,2006$.

LOPES, C.G.R.; BEIRÃO, D.C.C.; PEREIRA, L.A.; ALENCAR, L.C. Levantamento da flora apícola em área de cerrado no município de Floriano, estado do Piauí, Brasil. Revista Brasileira de Biociências. Porto Alegre, v. 14, n. 2, p. 102-110, 2016.

MOREIRA, A.S. Apicultura. Coordenadoria de Assistência Técnica Integral, 1996. 67 p. (Documento Técnico, 202). 


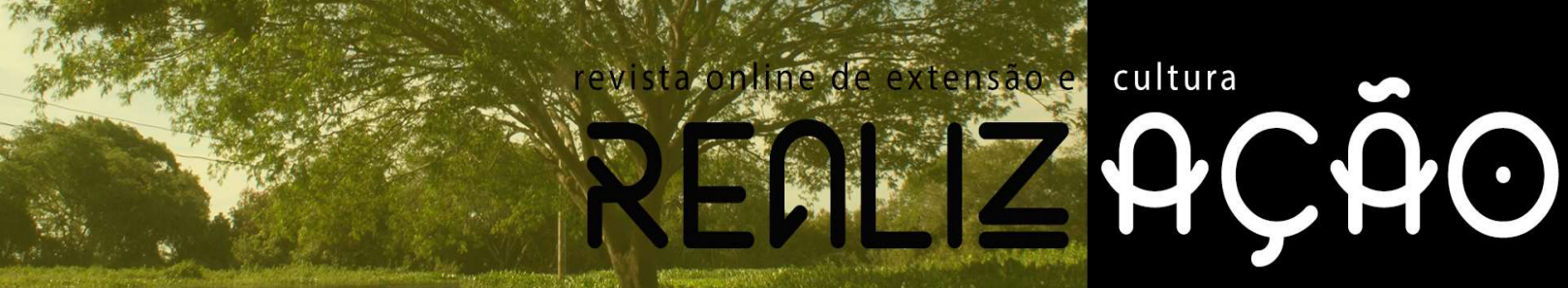

MUNIZ, E.B.; OLIVEIRA, E.R.; MENEGAT, A.S.; GABRIEL, A.M.A.; CARBONARI, O.S.; GANDRA, E.R.S.; GANDRA, J.R.; PEREIRA, T.L.; NUNES, F.P.; RODRIGUES, G.C.G.; CARMO, A.A.; GOUVEA, W.S. Apicultura na comunidade Areias em sistemas agroecológicos e de produção orgânica. Realização - Revista Online de Extensão e Cultura, n. 7, v. 4, p. 33-50, 2017.

PEIXOTO, J.F. Análise econômica da implantação de um apiário, voltado para produção de mel, como fonte alternativa de renda para pequenos produtores. 2000. Monografia (Graduação em Zootecnia) - Universidade Estadual de Maringá, Maringá, 2000.

REIS, V.D.A. Mel Orgânico: Oportunidades e Desafios para a Apicultura no Pantanal. Corumbá: EMBRAPA, 2003. 26p. (Documentos, 59).

RODRIGUES, G.S.; CAMPANHOLA, C.; KITAMURA, P.C.; IRIAS, L.J.M.; RODRIGUES, I.A. Sistema de avaliação de impacto social da inovação tecnológica agropecuária (AmbitecSocial). Embrapa Meio Ambiente, Jaguariúna: EMBRAPA, 2005. 30P. (Boletim de Pesquisa e Desenvolvimento 35).

ROVIRA, J. La apicultura como herramienta de desarrollo: proyectoBeeHoney. In: CONGRESO NACIONAL DE APICULTURA, 6, 2010, Córdoba. Resumos. 2010. Córdoba: Don Fólio, 2010. p. 29.

SEVILLA-GUZMÁN, E. Asociatividad y apicultura: orientaciones para undesarrollo local sustentable desde laagroecología, In: SIMPOSIUM MUNDIAL. Mendoza, Argentina. Resumos...Mendoza, 2004.

SOARES, A.E.E. Manejo de caixas iscas e suas implicações com a prevenção de acidentes. In: CONGRESSO BRASILEIRO DE APICULTURA, 12, Salvador, 1998. Anais...Salvador: Confederação Brasileira de Apicultura, 1998. p.61-65.

SOUZA, D.T.M.; COUTO, R.H.N.; COUTO, L.A.; SOUZA, J.C. Atrativo para as abelhas Apismellifera e polinização em café (Coffeaarábica, L.). Brazilian Journal of Veterinary Research and Animal Science, USP: São Paulo, n.40, v. 3, p. 272-278, 2003.

WIESE, H. Novo manual de apicultura. Guaíba: Agropecuária, 1995. 292 p.

WOLFF, L.F. Como instalar colméias. Brasília, DF: Embrapa Informação Tecnológica, 2010. 56 p. (ABC da Agricultura familiar, 25).

WOLFF, L.F.; MAYER, F.A. A apicultura no desenvolvimento agroecológico da reforma agrária no Rio Grande do Sul. Pelotas: Embrapa Clima Temperado, 2012. 84 p. (Documentos, $351)$. 